\title{
The Hijri and Gregorian Calendars: Comparison and Conversion
}

\author{
Fadhl Mohammed Mohammed Fushoosh*
}

Two calendars are in regular use in the Muslim world: the Gregorian and the Hijri. The Gregorian calendar is named after the Roman Catholic pope, Pope Gregory XIII, while the Hijri is named after the migration (hijrah) of Prophet Muhammad (peace be upon him) from his homeplace, Makkah to the town of Madinah in $622 \mathrm{CE}$. Islamic rituals are directly based on the hijrah as the greatest historical landmark marking the beginning of the era for the spread of Islam and establishment of the new Muslim polity. Thus, for a Muslim the Hijri calendar is not merely a calendar but a matter of identity of which s/he should be proud. However, the Muslim experience of colonisation and the subsequent imposition of the Gregorian calendar have led to the marginalisation of the Hijri calendar. Consequently many events are not known by the Muslims by their Hijri date. Many do not know how to determine the equivalent Hijri date. The Gregorian calendar was introduced by Pope Gregory in 1582, and underwent many modifications whereas the Hijri calendar remained as it started.

\section{From Julian Calendar to Gregorian Calendar}

The different calendars have adopted two systems in calculating the number of days in a year: the lunar calendar, which is based on moon cycles, and the solar calendar, which depends on the annual rotation of the sun. The definition of the seasons is related to the solar system.

Long after Jesus the Messiah (pbuh) departed this world, ${ }^{1}$ Christendom felt the need to define the Easter Day accurately, following the precedent believed to be established by the Nicene Council in $325 \mathrm{CE}$. The preceding Roman calendar had been divided between the two systems, the lunar and the solar. Although keen to observe the seasons which are definable only with reference to solar movement (years of 365.242199 days' duration), the Julian calendar initially followed the lunar system in numbering the days, and therefore, its year was 354 or 355 days. This is because the Easter period is specified with reference to both the vernal equinox and the full moon. This puts calculation of the Julian dates at variance with the seasons.

In 46 BC, Julius Caesar decreed that the year be 365 days instead of 354 days. Eleven days had to be added to the days of the year. Moreover, to approximate the number of days of the real solar year the Romans added one day (to February) every four years (leap years), thus creating an average of 365.25 days per year. 
This however, made them out of step with the moon's phases, although it retained the divisions invented by the Romans to mark the beginning and end of lunar months. By the sixteenth century the Julian calendar had drifted by four days out of the moon's phase. Moreover, there was a difference of eleven minutes and fourteen seconds every year amounting to ten days difference by the sixteenth century. ${ }^{2}$

Due to the solar/ lunar calculations involved in specifying Easter, the Julian calendar grew inconsistent and therefore created uncertainty within Christendom. ${ }^{3}$ Pope Gregory ordered then that ten days be deleted from the calendar. Thus days from 4 October, 1582 to 15 October, 1582 were expunged to make the date as close as possible to the actual date. Moreover, it was ruled that any century year indivisible by 400 would not be considered a leap year. After all these modifications the number of days in the year became 365.2425, as opposed to the real solar yearly period of 365.242199 days. This slight difference has been ignored until today. ${ }^{4}$

\section{The Hijri Calendar}

The Hijri calendar is a lunar calendar devised by the Muslims under the decree of caliph 'Umar bin Al-Khattab. The normative feature marking the beginning, middle and end of the month is the moon phases. The names of the twelve lunar months begin with Muharram, then Safar, Rabi' al-awwal, Rabi' al-thani, Jumada al-awwal, Jumada al-thani, Rajab, Sha'ban, Ramadan, Shawwal, Dhu alQai'dah, and Dhu al-Hijjah. The Islamic religious obligations are based on this calendar. The annual fasting ritual is decided by sighting the new moon (hilal) at the beginning and end of the Ramadan month. The annual zakat payment is determinable on the basis of the end of a cycle of one lunar year. Also, the hajj (pilgrimage) period is fixed according to specific dates in the lunar year. Each month may be of 29 or 30 days' duration depending upon astronomical positioning of the earth and moon, and weather conditions. The lunar year is of approximately 354 days' duration. The eleven day difference from the solar year is one of the wisdoms allowing for variation over time as fasting falls on different seasons throughout the Metonic cycles. ${ }^{5}$

\section{Excellent Characteristics of the Hijri Calendar}

1. It is a wholly divine system - the length, sequence, beginning and end of the months are determined by God. The astronomers have no authority but to apply the system, which is equally observable by ordinary people. The experts and the most intellectually challenged alike can observe the beginning and end of the month and act accordingly in their religious duties. 
2. The solar-lunar difference is a chance for Muslims to enjoy performing their rituals in various seasons. Thus, s/he would sometimes fast in the spring, summer, autumn and winter, with differing lengths of fasting time according to the seasons. The approximate cyclic return of the same seasonal position for the Hijri calendar date occurs every 33 years of the Gregorian calendar.

3. Following the Hijri calendar is part of the Muslims' identity. This makes them stand distinct among other cultures and proud of possessing a system that has been consistent and in perfect conformity with their obligations.

4. It is simple and precise. Only one system is followed, i.e. the lunar. The Roman calendar however, was modified by Julius Caesar, and named after him; similarly, the Julian calendar was modified into the Gregorian, all to redefine the day of Easter which was celebrated at different times by different churches. These were not consistent, and therefore many modifications and calculations had to be considered to bring the Easter observance into harmony with the progression of time. Moreover, for the Gregorian calendar, expertise is needed for complicated calculations. The Hijri calendar is free from such complications and every Muslim can perform his rituals with confidence. He can personally check to ensure no one misleads him in defining the days when he should perform his obligations. Further, unlike the European calendars, the Hijri has been consistent from the very beginning and thus is in no need of reform.

5. Political authorities played vital roles in the Gregorian, Julian and Roman calendars. For example, the number and names of days were tampered with. In $8 \mathrm{CE}$, Augustus changed the name of the sixth month (in the Roman year) to August to commemorate his achievements. Similarly, Julius Caesar named the fifth month after himself. They also changed the number of days in the months. They made February 28 days and the rest 30 and 31. The Hijri calendar is totally determined by Allah and man has no authority over it. God says in the Qur'an: "Verily, the number of months in the sight of Allah is twelve [in a year]; so ordained by Him the day He created the heavens and earth; of them four are sacred months." "Furthermore, he condemned those who make any changes where they defer some months and make substitution between them. ${ }^{7}$

6. The Hijri calendar started as the name indicates with the hijrah year of Prophet Muhammad (pbuh). By contrast, the date of birth of Jesus Christ (pbuh) did not mark the beginning of the Gregorian year. Some Christian scholars believe his birth was actually in $6 \mathrm{BC}$ yet they are still adamant in citing the year as Anno Domini meaning "Year of the Lord". 


\section{Hijri-Gregorian Conversions ${ }^{8}$}

a. To Convert Gregorian (hereafter CE) to Hijri (hereafter AH)

Year 2015 is converted into a Hijri year using the formula:

$$
\frac{\mathrm{CE}-622}{0.97} \frac{2015-622}{0.97}=\frac{1393}{0.97}=1436.082474226804
$$

Since the decimal fraction is less than 0.5 it is ignored, and the remaining number 1436 is the present Hijri year.

\section{b. To Convert the Hijri to Gregorian}

The Hijri year (AH) is converted to Gregorian (CE) using the formula: $(\mathrm{AH} \times 0.97)+622$

Year $1436 \mathrm{AH}$ is thereby converted to Gregorian, as follows:

$$
(1436 \times 0.97)+622
$$

$1392.92+622=2014.92$. Since the fraction is more than 0.5 , it should be counted as one, which when added to 2014 becomes 2015, the current CE year.

\section{Notes}

* Fadhl Mohammed Mohammed Fushoosh is Phd research scholar at Aligarh Muslim University, India. He can be contacted at fushoosh2@gmail.com.

1. According to the Quran, Jesus (pbuh) did not die as Allah raised him up to heaven (Q4:157-158).

2. (365.25-365.242199) days X1300, since the Council of Nicaea in 325 CE.

3. The Church of Alexandria celebrated Easter on the Sunday after the $14^{\text {th }}$ day of the Moon (computed using the Metonic cycle) that falls on or after the vernal equinox, which they placed on March 21. However, the Church of Rome still regarded March 25, as the equinox and used a different cycle to compute the day of the Moon. By the $10^{\text {th }}$ century all churches (except for some on the eastern border of the Byzantine Empire) had adopted the Alexandrian Easter, which still 
placed the vernal equinox on March 21; although Bede had already noted its drift in 725 - it had drifted even further by the $16^{\text {th }}$ century. http://en.wikipedia.org/ wiki/Gregorian_calendar (Accessed 10-3-2015).

4. The difference may amount to one day in 3,322 years.

5. The Metonic cycle is a period close to 19 years, which is nearly a common multiple of the solar year and lunar month periods.

6. The Qur'an 9:36

7. The Qur'an 9:37.

8. All calculations are approximate. 